\title{
Legal Aspects of Electricity Produced from RES in SR
}

\author{
Ján Gaduš jr. ${ }^{1)}$ and Tomáš Giertl ${ }^{2)}$ \\ 1) Slovak University of Agriculture in Nitra, Department of Law, Nitra, Slovakia, e-mail: jankogadus@pobox.sk \\ 2) Slovak University of Agriculture in Nitra, Department of Regional Bioenergy, Nitra, Slovakia, \\ e-mail: tomas.giertl@uniag.sk
}

\begin{abstract}
The paper deals with the promotion of the use of RES in the area of electricity production in Slovakia. To promote the use of RES for electricity generation a system of subsidies as well as exemptions from the excise duty on electricity produced from RES have been introduced. The most important support mechanism for the use of RES in Slovakia in general, and within the field of electricity production from RES, are the feed-in tariffs. They are very effective and easy to implement, but carry certain risks. However, in 2016 the share of RES in gross final energy consumption dropped compared to previous year so the government prepared some amendments to the law.
\end{abstract}

Keywords - renewable energy sources (RES), electricity production, support mechanism systems, feed-in tariffs, amendment.

\section{INTRODUCTION}

The main goal of the paper is, to provide an overview of support mechanism systems of renewable energy sources (RES) in the Slovak legal framework, in particular in the field of electricity production, the objective of which is to increase the share of RES in the production of electricity, heating and cooling and their use in transport, and its impact on the achievement of ongoing objectives and targets set in the Slovak National Plan and Directive 2009/28/EC.

Methodological approach chosen for the paper is studying the laws of the Slovak Republic and legislation of the European Union, technical and scientific literature from domestic and foreign sources. The methods used in the paper were: scientific observation for the purpose of data collection from various available databases and the subsequent comparison, analysis and synthesis of the laws of the Slovak Republic and the European Union, which promote the use of RES in the field of electricity production.

Given current market conditions, RES are nevertheless in many cases still more expensive than conventional sources. The long-term costs of conventional means for energy generation, in particular in terms of the exploitation of resources and climate change, have only just begun to influence prices. Therefore RES have need for legal "guideposts" in order to be able to balance out the economic disadvantage, assert themselves on the market and gradually replace conventional energy sources [17].

Energy markets on their own cannot deliver the desired level of renewables in the EU, i.e. national support schemes may be needed to overcome this market failure and spur increased investment in RES. If these public interventions are not carefully designed, their lack can distort functioning of the energy market and lead to higher costs for European households and businesses.

\section{EUROPEAN PERSPECTIVE}

The promotion of new and renewable energy forms is a part of the EU policy on energy. The market does not provide the optimal level of renewables if there is the absence of public intervention [5]. Slovakia as a member state of the European Union (EU) is obligated to follow EU's legislations, policies and regulations.

The EU energy strategy for current period is defined in the 2020 Energy Strategy, under which the main goals are to lower the greenhouse gas emissions by at least $20 \%$, to raise the use of RES to at least $20 \%$ and to accomplish energy savings of $20 \%$ by the year 2020 [1]. For the next period the aims are defined in the 2030 Energy Strategy and they are a $40 \%$ reduction of the greenhouse gas emissions compared to 1990 levels, at least a $27 \%$ share of renewable energy consumption and at least $27 \%$ energy savings compared with the business-as-usual scenario [2]. Although the EU goals set for the year 2030 have not been up to the date officially changed, in the prepared text of the revision of the Directive 2009/28/EC, which was agreed upon and waits to be formally adopted by the European Council and Parliament, the set goals are new ones for the year 2030. The provisional agreement sets a $32 \%$ binding EU target for RES by 2030. As for the transport sector, the agreement sets a $14 \%$ RES target by 2030 , a $3.5 \%$ share of advanced biofuels and biogas (1\% by 2025), a $7 \%$ cap on the share of first-generation biofuels in road and rail transport, and plans to phase out the use of palm oil (and other food-crop biofuels that negatively impact $\mathrm{CO} 2$ emissions) through a certification scheme. Consumer rights to the RES self-consumption are strengthened, the energy efficiency first principle is to become a guiding one, and an indicative annual increase of $1.3 \%$ for RES in heating and cooling is introduced [8].

The basis for the legal framework of the EU is settled in the Article 194, Clause 1 of the Treaty on the European Union and the Treaty on the Functioning of the European Union, in which it is stated, that in the context of the establishment and functioning of the internal market and with regard to the need to preserve and improve the environment, the EU policy on energy shall aim, in the spirit of solidarity between the Member States, to ensure 
the functioning of the energy market, ensure security of energy supply in the EU, promote energy efficiency and energy saving and the development of new and renewable forms of energy and promote the interconnection of energy networks.

The main legal source in the EU is the Directive 2009/28/EC of the European Parliament and of the Council of Europe of 23 April 2009 on the promotion of the use of energy from renewable sources (the Directive). The Directive is currently undergoing a revision.

The Directive in the Article 3, Clause 1 requires each Member State by 2020 to achieve at least the same share of energy produced from RES as the national target for the share of energy from renewable sources. In the Article 3, Clause 4 of the Directive is stated, that each Member State should ensure that the share of energy from RES in all forms of transport in 2020 is at least $10 \%$ of the final consumption of energy in transport in that Member State. The Directive also defines the system of support, while purchase prices are among the key motivational tools for the support of RES.

As support mechanism systems, or as stated in the Directive, under the support scheme is considered any instrument, scheme or mechanism applied by a Member State or a group of Member States, that promotes the use of RES by reducing the cost of that energy, increasing the price at which it can be sold, or increasing, by means of a renewable energy obligation or otherwise, the volume of such energy purchased. This includes, but is not restricted to, investment aid, tax exemptions or reductions, tax refunds, renewable energy obligation support schemes including those using green certificates, and direct price support schemes including the feed-in tariffs and premium payments.

The EU also adopted guidance for the EU countries when designing and reforming renewable energy support schemes. Firstly, this guidance suggests that financial support for renewables should be limited to what is necessary and should aim to make renewables competitive in the market. Secondly, the support schemes should be flexible and respond to the falling production costs. As technologies mature, schemes should be gradually removed. For instance, the feed-in-tariffs should be replaced by the feed in premiums and other support instruments that incentivize producers to respond to market developments. Then, unannounced or retroactive changes to the support schemes should be avoided as they undermine investor confidence and prevent future investments. Finally, the EU countries should take advantage of the renewable energy potential in other countries via cooperation mechanisms. This would keep costs low for consumers and boost investor confidence [15].

\section{SUPPORT MECHANISM SYSTEMS IN SLOVAKIA}

In the National Energy Action Plan for energy from RES from October, 2010 for the energy based on RES, national objectives for its share in the transport, electricity, heat and cold production are set up to 2020. In the period Slovakia is obliged to increase the use of renewable energy up to $14 \%$ of the gross final energy consumption (in 2005 it was $6.7 \%$ ) and the share of energy from RES in all forms of transport to at least $10 \%$ of the final consumption of energy in transport.
The main legal source promoting the use of RES in Slovakia is the Act No. 309/2009 Coll. on the promotion of renewable energy sources and high-efficiency cogeneration (RES Act). Currently the RES Act is being reviewed as well as the Directive. On August 22, 2018 the Slovak Government passed its proposed amendment to the RES Act and is waiting to be passed in the Slovak Parliament.

The RES Act defines the conditions for supporting RES and high efficiency combined heat and power (CHP) production (mostly electricity and bio methane production), rights and duties of electricity producers, distribution network operators and producers of bio methane, the rules for issuing certificates of origin for electricity produced from RES and high efficiency CHP and bio methane, pricing rules and obligations for state administration bodies. The RES Act targets all scale of RES electricity and CHP generation (up to $200 \mathrm{MW}$ ).

Under the RES Act, RES and high efficiency CHP electricity producers would be entitled to preferential transmission, distribution and delivery of their electricity. The system operators would also be required to buy RES and highly efficient CHP electricity at a preferential fixed purchase price for investment period of 15 years.

The price would be set by the Regulatory Office for the Network Industries (RONI). The RES Act defines the input data (general and technical parameters) the application must include; the guarantee of origin is issued by the RONI after the verification of the data and relevant calculations evaluation. Among other provisions, the RES Act lays down a support system for electricity production from RES and high-efficiency CHP, as well as the production of bio methane (a biogas), and outlines electricity producer rights and obligations, as well as those of other market participants.

For producers, false information regarding the origin of electricity from RES or failure to comply with other provisions can entail fines ranging from 500.00 EUR up to 100,000.00 EUR. A distribution system operator (DSO) that doesn't allow access, connection or transmission of green electricity can face fines from 10,000.00 EUR up to 200,000.00 EUR. A DSO can also face fines of 500.00 EUR to $100,000.00$ EUR for failure to comply with the RES Act. [3] especially confusing. Write "Magnetization $(\mathrm{kA} / \mathrm{m})$ " or "Magnetization $\left(10^{3} \mathrm{~A} / \mathrm{m}\right)$." Figure labels should be legible, about 10-point type.

\section{A. Support Mechanism for the Use of RES in Slovakia within the Field of Electricity Production}

Support mechanism systems promoting the use of RES for electricity production in Slovakia are the feed-in tariff, subsidies and tax regulation mechanisms (exemption from excise tax).

Provisions for the electricity production under RES Act are:

- Preferential connection and access to the grid, as well as preferential transmission, distribution and supply;

- Mandatory off-take by regional DSO for the price of electricity losses (stable prices for 15 years);

- A bonus price, stable for 15 years;

- Responsibility for deviations assumed by regional DSO;

- $\quad$ Certificates of origin [3]. 
The subsidies for the investment projects regarding the production of electricity from RES are financed from two basic sources, the Operational Program Quality of Environment (OPQE) and Environmental Fund (EF).

The OPQE allocates investment grants from the European Regional Development Fund (ERDF) for the natural and legal entities, associations or non-profit organizations. The renewable energy projects are eligible under the Priority Axis 4 "Energy-efficient low-carbon economy in all sectors", namely the Investment Priority 4.1 "Promoting the production and distribution of energy derived from renewable sources".

The specific Target 4.1.1 "Increasing the share of RES in gross final energy consumption of the SR" is aimed at supporting the generation of heat and electricity from RES, thereby contributing to the achievement of the planned share of RES in the gross final energy consumption by 2020. Eligible activities under this target include the replacement of inefficient solid fuel fired boilers with heat generating plants fired by biomass as well as the construction of heat pumps, biogas, and solar thermal or geothermal plants.

The bodies eligible for subsidies are the natural or legal entities authorized to conduct business, associations, local government bodies or non-profit organizations. Projects must be implemented outside the Bratislava region. However, households from the Bratislava region could apply for installations of 'small sources' with total installed capacity up to $10 \mathrm{~kW}$ [14].

Under the Act No. 587/2004 Coll. on the Environmental Fund, the EF may be provided and used for installation of new equipment that uses as a source RES, geothermal energy or secondary energy sources (under secondary energy sources is understood an energy source energy potential of which comes from the gas byproduct generated in the production processes and technological processes); for reconstruction or modernization of existing facilities that use as an energy source RES or secondary energy sources; for exchange or reconstruction of existing facilities, which by the preparation of heat, hot water and by cooling are using fossil fuels; for facilities using biomass, secondary energy source or geothermal energy; for heat pumps or for solar collectors, including the exchange of the whole system and its reconstruction; for installation of new facilities, which by the preparation of heat, hot water and by cooling will use biomass, secondary energy source or geothermal energy, installation of heat pumps or installation of solar collectors, including installation of the entire system.

The tax regulation mechanisms, which promote the use of RES in electricity production, are stated in the Act No. 609/2007 Coll. on excise duty on electricity, coal and natural gas. Under this Act exemption from excise duty applies to electricity produced from a renewable source, if such production is demonstrated using a guarantee of origin of electricity produced from the renewable energy sources and if such electricity was generated in a solar facility, or a wind power plant, or a facility designed for the use of geothermal energy, or a hydroelectric power plant or a facility designed for the use of biomass or a product produced from biomass.

The Slovakia electricity production from RES is supported mainly through a fixed feed-in tariff. The tariff consists of two parts, the price of electricity for losses (market price) and a surcharge. The market price is paid for all electricity supplied from the RES facilities up to support limit facilities of an electricity producer with the total installed capacity up to $125 \mathrm{MW}$, or with the total installed capacity up to $200 \mathrm{MW}$, if electricity is produced from high efficiency cogeneration and the energy ratio of the renewable energy sources in the fuel is higher than $20 \%$.

The regional DSO is obliged to enter into agreements on the electricity supply to cover losses in the distribution grid with the electricity producers. The DSO is obliged to take all electricity that was generated by the electricity producer entitled for support.

The RES plant operator must have a license to produce electricity issued by RONI, a pricing decision on the amount of the feed-in price, and separate metering of the RES-produced electricity via a certified meter. Based on the amount of electricity measured, the plant operator submits information on the electricity production to the regional distribution system operator and invoices that amount [6].

Prices of electricity generated from RES (determined like fix prices in EUR/MWh) in accordance with the Decree No. 18/2017 of RONI for all energy production facilities have been put into operation from January 1, 2017:

a) electricity produced from hydro energy in a facility with a total installed capacity

1. up to $100 \mathrm{~kW}$

2. from $100 \mathrm{~kW}$ to $200 \mathrm{~kW}$

3. from $200 \mathrm{~kW}$ to $500 \mathrm{~kW}$

4. from $500 \mathrm{~kW}$ to $1 \mathrm{MW}$

5. from $1 \mathrm{MW}$ to $5 \mathrm{MW}$

b) electricity produced from solar energy in a facility with a total installed capacity up to $30 \mathrm{~kW}$, placed on the roof or external cladding of one building, connected with soil by its footing and registered in a respective real estate register (cadastre)

c) electricity produced from wind energy

d) electricity produced from geothermal energy

e) electricity produced from combustion or co-firing using combined energy production

1. purposely grown biomass excl. cereal straw

2. other waste biomass excl. cereal straw

3. cereal straw

4. bio liquids

f) electricity produced from co-firing of biologically decomposable fragments of municipal waste with fossil fuels
111.25 EUR/MWh 109.15 EUR/MWh 106.80 EUR/MWh 105.11 EUR/MWh 97.95 EUR/MWh

84.98 EUR/MWh

44.18 EUR/MWh

108.71 EUR/MWh

$70.31 \mathrm{EUR} / \mathrm{MWh}$

74.30 EUR/MWh

92.17 EUR/MWh

80.86 EUR/MWh

70.83 EUR/MWh 
g) electricity produced from combustion

1. gas from sewage tank or waste dump

2. biogas obtained by means of anaerobic fermentation technology with capacity up to $1 \mathrm{MW}$

3. biogas obtained by anaerobic fermentation technology with capacity up to $250 \mathrm{~kW}$

4. biogas obtained by anaerobic fermentation technology with capacity from $250 \mathrm{~kW}$ to $500 \mathrm{~kW}$

5. biogas obtained by anaerobic fermentation technology with capacity from $500 \mathrm{~kW}$ to $750 \mathrm{~kW}$

6. biogas obtained by anaerobic fermentation technology with capacity over $750 \mathrm{~kW}$

7. gas obtained by thermochemical gasifying in generator

8. fermented mixture obtained by anaerobic fermentation technology produced from biologically decomposable fragments of municipal waste

58.66 EUR/MWh

95.95 EUR/MWh

102.00 EUR/MWh

95.89 EUR/MWh

91.61 EUR/MWh

90.02 EUR/MWh

84.72 EUR/MWh

Prices of the electricity generated from a highly effective combined production (determined like fix prices in EUR/MWh) in accordance with the Decree No. $18 / 2017$ of RONI for all energy production facilities have been put into operation from January 1, 2017:

a) in combustion turbine with combined cycle

b) in combustion turbine with heat regeneration

c) in combustion engine with fuel

1. natural gas

2. fuel oil

3. mixture of air and methane

4. from catalytically processed waste

5. from thermic fissure of waste and its products

d) in back-pressure turbine or in condensation turbine with heat take-off with fuel
1. natural gas
2. fuel oil
3. brown coal

74.10 EUR/MWh

74.05 EUR/MWh

75.04 EUR/MWh

73.67 EUR/MWh

68.90 EUR/MWh

92.63 EUR/MWh

85.11 EUR/MWh

67.90 EUR/MWh

68.29 EUR/MWh
67.10 EUR/MWh
4. black coal with a total installed capacity up to $50 \mathrm{MW}$ including

62.81 EUR/MWh

5. black coal with a total installed capacity above 50 MW

6. municipal waste

59.26 EUR/MWh

62.51 EUR/MWh

7. gas obtained by thermochemical gasifying of waste in generator or thermic fissure

e) from combustion of usable gases arising in steel production process

f) in Rankin's organic cycle

EUR/MWh

98.31 EUR/MWh

\section{B. Evaluation of Support Mechanism Systems in Slovakia}

When comparing the current support mechanism system implemented in Slovakia to current support mechanism systems, which are provided by the Directive, Slovakia uses only systems that are the most elementary and easy to implement. When considering the guidance for the EU countries for designing and reforming the renewable energy support schemes, Slovakia meets the proposal of avoiding the unannounced or retroactive changes and in some way also the proposal of flexibility and respond to falling production costs. On the other hand, financial support for RES is not limited to what is necessary and Slovakia is not involved in any cooperation mechanisms with other countries.

Since in Slovakia as well as in the Directive the system of the feed-in tariffs is considered to be the key tool for promoting RES and because the support mechanism systems of RES in the field of electricity production are the main topic of the paper, further evaluation will concern only this support mechanism system. Support for the electricity from RES through the feed-in tariffs is the most widespread support within the EU. Historical tracking of the support of RES in the Member States shows that the biggest penetration of RES was recorded in using the system of the feed-in tariffs and that in the system lower costs for consumers have been introduced.

Besides obvious benefits for the investors in the form of guaranteed stability of the purchase prices, this system brings several risks. In particular, an increase of the electricity prices, the impact on the stability and security of the electricity system and the inadequate support of reconstructed facilities has been recorded.

With regard to the risk of increased prices, this was gradually eliminated, because the guaranteed purchase prices for green electricity paid by all consumers in their electricity bills are gradually declining. For example, investors who built a solar power station in Slovakia at the turn of 2009-2010, are over fifteen years entitled to the purchase price amounting up to 430.00 EUR per megawatt hour. If the solar plant was built this year, they would be entitled to the purchase price of less than 85.00 EUR per megawatt hour [4]. However, even though there still are some risks that can increase the price, such as the tariff for system operation, which is a part of the final price of electricity and is also included in the payment for the support. The government, however, has a plan to minimize these effects, particularly with respect to the final consumers [16]. As to stability and security of the 
electricity system, due to the fact that the purchase prices are subject to compliance obligations under the RES Act, in case of failure to comply there is a risk of losing entitlement for support. If the green electricity producers want to claim for the state support in the form of higher purchase prices for the electricity they produce, they must inter alia fulfil two statutory obligations. Until April 15 of the current year they have to return an excess payment to DSO for the previous year, they are not entitled to. And they must also notify RONI and DSO by August 15 of the current year that they will apply for the support in the next calendar year, including the expected amount of electricity supplied to them [7]. In 2014, for example, nearly 1.200 out of the more than three thousand producers of green electricity lost the support, because of their failure to notify RONI and DSO [9]. Loosing the support may be for some producers of green electricity liquidating, which may ultimately have an impact on the overall stability and security of the electricity system.

Inadequate support for reconstructed facilities has been minimized with the amendment to the RES Act which took effect from $1^{\text {st }}$ February 2011 by redefining the definition for assessing the reconstruction of the technological part of the electricity producer in a way that the reconstruction and modernization of the technological part requires excess of $50 \%$ of the investment cost for a new comparable technological part.

TABLE I

SHARE OF RENEWABLE ENERGY IN GROSS FINAL ENERGY CONSUMPTION

\begin{tabular}{|c|c|c|c|}
\hline \multirow{2}{*}{ Year } & \multicolumn{2}{|c|}{ SR } & EU28 \\
\cline { 2 - 4 } & Real share & Target & Real share \\
\hline 2010 & $9,1 \%$ & $9,5 \%$ & $12,9 \%$ \\
\hline 2011 & $10,3 \%$ & $8,2 \%$ & $13,2 \%$ \\
\hline 2012 & $10,4 \%$ & $8,2 \%$ & $14,4 \%$ \\
\hline 2013 & $10,1 \%$ & $8,9 \%$ & $15,2 \%$ \\
\hline 2014 & $11,7 \%$ & $8,9 \%$ & $16,1 \%$ \\
\hline 2015 & $12,9 \%$ & $10,0 \%$ & $16,7 \%$ \\
\hline 2016 & $12,0 \%$ & $10,0 \%$ & $17,0 \%$ \\
\hline
\end{tabular}

*Source: Eurostat \& the National Energy Action Plan for energy from RES from October, 2010.

Slovakia is fulfilling its projected goals, although a small set back can be seen when comparing the last two years. The share of RES in the gross final energy consumption has dropped by $0.9 \%$ from $12.9 \%$ in 2015 to $12 \%$ in 2016. Nevertheless, despite this set back, Slovakia is still $2 \%$ above its projected goal for the share of RES in the gross final energy consumption in 2016, which was set to $10 \%$. But the overall use of RES in Slovakia is below the EU average.

Currently the situation of the share of RES in the Slovak economy is not alarming, but considering the decreasing feed-in tariffs, what is making the investment into facilities that use RES less attractive. New measures for the support of RES in Slovakia, which are being prepared, should urgently be introduced.

From September 2018 a strategic document entitled "Greener Slovakia: Environmental policy strategy of Slovak republic for 2030" is a part of the legislative procedure. It contains 20 strategic goals for environment, from which only one linked to RES. This goal related to RES states that the Ministry of the Environment of the Slovak Republic should adopt criteria for a sustainable development upon which the support of the energy production will be granted to those producers of energy from RES, which by their nature do not burden the environment and contribute to the long-term sustainable development of the Slovak Republic and to the improvement of the environment compared to the traditional sources of energy [12].

In the legislative procedure there is also the review of the RES Act. On August 22, 2018 Slovak Government passed its proposed amendment of the RES Act and is waiting to be passed by the Slovak Parliament.

According to the amendment approved by the Government, the electricity produced from RES by new larger plants with a capacity over $500 \mathrm{~kW}$ should be supported only through auctions where the state will choose a plant for the production of electricity from RES, which they will support. The final price of electricity produced from RES will be the result of a competition. However, the rights of existing manufacturers will be preserved.

The current setting of the system for the support of electricity produced from RES imposes an obligation on the regional distribution system operators to purchase the supported electricity used to cover the losses in the system. The purchase of the supported electricity after the introduction of the reform will be taken over by the electricity buyer, so there will be just the only one purchaser established.

The amendment also introduces an incentive for energy-intensive businesses. The draft of the law provides for the businesses that meet the conditions specified by the law compensation, which is a reduction of the costs consisting of the tariff for system operation.

Another important novelty is a new legal term of so called "local power plant", which is a plant with a capacity up to $500 \mathrm{~kW}$, which is designed exclusively for the consumption at a given point of supply without any significant impact on the overall electricity system and without any additional costs, such as payment of the tariff for system operation [13].

Critics of the above mentioned amendments to the RES Act say, that because the state auction selection of the larger producers of the electricity from RES, who will be supported, the final price of the electricity produced from RES will not be created by the market, but by the state. Another critical point is also the compensation for the energy-intensive businesses. Critics point out that because it is only for a limited number of businesses, only "the chosen one" will be preferred and supported. Critics also say that the prepared amendment to the RES Act is not in line with the prepared review of the Directive, because the prepared review of the Directive does not consider the support of the high-efficiency cogeneration plant while the amendment of the RES Act keeps this support in effect [11].

On the other hand, the Institute of Economic and Social Studies evaluates (the INESS) the amendment rather positive than negative. According to the INESS the amendment to the RES Act brings changes that have the potential to influence the future value of the tariff for system operation. A key change is the introduction of an auction system for larger RES installations. This should ensure that, along with significantly cheaper technologies, future green electricity payments are significantly lower than in the past [10]. 


\section{CONCLUSION}

Slovakia is currently meeting the objectives and targets, stated in its National plan and resulting from the Directive, just by applying the basic support mechanism systems of RES, as the feed-in tariffs, tax support mechanisms, subsidies and quotas. The result of these low efficient measures is that Slovakia is below the EU average of the share of energy from the renewable sources and finds itself at the bottom of the list of EU countries as to the share of energy from the renewable sources.

It must also be mentioned that Slovakia doesn't follow all the recommendations that are proposed in the guidance for the EU countries for designing and reforming the renewable energy support schemes. So, in the future, Slovakia should introduce into its legal framework new support mechanism systems of RES or amend the current ones in order to be in line with the guidelines for the EU countries when designing and reforming the renewable energy support schemes, particularly in the field of electricity production. Even though the government has approved the amendment to the RES Act and it has been moved forward, e. g. with the introduction of the auction system and the legal term of "local power plant", there are still many factors that have to be solved. The amendment lacks mainly concrete criteria for the selection of the auction winner for whom the support will be granted and concrete criteria for the selection of the energy-intensive businesses for which the compensation will be granted. The question whether the prepared amendment to the RES Act is or is not in line the prepared review of the Directive cannot be jet answered, because neither of them has been officially adopted. In other words, the proposed texts of both novelties can still be changed, so the final versions are unknown at the moment (September 2018). However, it must be stressed once more, that the national legislation must be in line with the EU directives, and that is why because the review of the Directive is nearing its adoption by the European Council and Parliament, it would be advisable to postpone the adoption of the amendment to the RES Act until the review of the Directive is adopted.

\section{ACKNOWLEDGMENT}

This work was supported by the AgroBioTech Research Centre built in accordance with the project Building „AgroBioTech" Research Centre ITMS 26220220180.

\section{REFERENCES}

[1] “2020 Energy Strategy,” European Commission. [Online]. Available: European Commission, https://ec.europa.eu/energy/en/ topics/energy-strategy-and-energy-union/2020-energy-strategy [Accessed: 20 Sep. 2018].

[2] "2030 Energy Strategy," European Commission. [Online]. Available: European Commission, https://ec.europa.eu/energy/en/ topics/energy-strategy-and-energy-union/2030-energy-strategy [Accessed: 20 Sep. 2018].

[3] "Act No. 309/2009 on Support of Renewable Energy Sources and High Efficiency CHP," International Energy Agency. [Online]. Available: International Energy Agency, http://www.iea.org/ policiesandmeasures/pams/slovakia/name-24496-en.php [Accessed: 16 Apr. 2017].
[4] "Comparison of RES support and redemption prices of electricity produced from RES in neighboring countries" [Porovnanie podpory OZE a výkupných cien elektriny vyrobenej z OZE v okolitých krajinách], Martin, 2016.

[5] "European Commission guidance for the design of renewables support schemes," Brussels, 2013.

[6] "Feed-in tariff," RES LEGAL, [Online]. Available: Renewable energy policy database and support, http://www.res-legal.eu/searchby-country/slovakia/single/s/res-e/t/promotion/aid/feed-in-tariff6/lastp/187/ [Accessed: 16 Apr. 2017].

[7] "Green electricity producers have obviously learned" [Výrobcovia zelenej elektriny sa zrejme poučili], V Energetike.sk, [Online]. Available: venergetike.sk, http://venergetike.sk/vyrobcovia-zelenejelektriny-sa-zrejme-poucili/ [Accessed: 16 Apr. 2017].

[8] J. Blanco López, "JD - Review of the Renewable Energy Directive 2009/28/EC to adapt it to the EU 2030 climate and energy targets." European Parliament, July 2018, [online]. Available: European Parliament, http://www.europarl.europa.eu/legislative-train/themeresilient-energy-union-with-a-climate-change-policy/file-jdrenewable-energy-directive-for-2030-with-sustainable-biomassand-biofuels [Accessed: 20 Sep. 2018].

[9] "Judgement did not stop the withdrawal of green electricity producers" [Súd nezastavil odoberanie podpory výrobcom zelenej elektriny], V Energetike.sk, [Online]. Available: venergetike.sk, http://venergetike.sk/sud-nezastavil-odoberanie-podporyvyrobcom-zelenej-elektriny/ [Accessed: 16 Apr. 2017].

[10]M. Vlachynský. INESS NA TÉMU, INESS - INSTITUTE OF ECONOMIC AND SOCIAL STUDIES, no. 7, 2018, pp. 1-4. [online].

[11]R. Potočár, "Galek: The new act on support of RES can raise the prices of electricity and harm producers" [Galek: Nový zákon o podpore OZE môže zvýšit' ceny elektriny a poškodit' výrobcov.], Energie-portal.sk, 18.05.2018 [online]. Available: PROPERTY \& ENVIRONMENT, https://www.energie-portal.sk/Dokument/galeknovy-zakon-o-podpore-oze-moze-zvysit-ceny-elektriny-a-poskoditvyrobcov-104406.aspx [Accessed: 20 Sep. 2018].

[12]R. Potočár, "The state wants to design "a criteria of sustainable development" for RES. They are going to be decisive for granting support” [Štát chce pre OZE vypracovat' „kritériá udržatel'nosti. Budú rozhodovat' o podpore.], Energie-portal.sk, 11.09.2018 [online]. Available: PROPERTY \& ENVIRONMENT, https://www.energie-portal.sk/Dokument/galek-novy-zakon-opodpore-oze-moze-zvysit-ceny-elektriny-a-poskodit-vyrobcov104406.aspx [Accessed: 20 Sep. 2018].

[13]R. Potočár, "The state wants to reform the support for RES. The government has approved major changes." [Štát chce reformovat' podporu OZE. Vláda odobrila rozsiahle zmeny.], Energie-portal.sk, 22.08.2018 [online]. Available: PROPERTY \& ENVIRONMENT, https://www.energie-portal.sk/Dokument/galek-novy-zakon-opodpore-oze-moze-zvysit-ceny-elektriny-a-poskodit-vyrobcov104406.aspx [Accessed: 20 Sep. 2018].

[14]"Slovakia: Summary: Support schemes," RES LEGAL, [Online]. Available: Renewable energy policy database and support, http://www.res-legal.eu/search-by-country/slovakia/summary/c/ slovakia/s/res-hc/sum/188/lpid/187/ [Accessed: 16 Apr. 2017].

[15] "Support schemes," European Commission, [Online]. Available: European Commission, https://ec.europa.eu/energy/en/topics/ renewable-energy/support-scheme [Accessed: 16 Apr. 2017].

[16]"They want to restrict the support of renewable energy sources by electricity generation" [Podporu obnovitel'ných zdrojov pri výrobe elektriny chcú obmedzit'], venergetike.sk, [Online]. Available: venergetike.sk, http://venergetike.sk/podporu-obnovitelnychzdrojov-pri-vyrobe-elektriny-chcu-obmedzit/ [Accessed: 16 Apr. 2017].

[17]V. Oschmann, "Introduction to European Law on Renewable Energy Sources". 